\title{
Australia Day, flags on cars and Australian nationalism
}

\author{
Farida Fozdar \\ Professor \\ Anthropology and Sociology \\ The University of Western Australia \\ Brian Spittles \\ The University of Western Australia \\ Lisa Hartley \\ Curtin University \\ The University of Western Australia
}

This paper reports the results of research into the recent popular phenomenon of flying Australian flags on one's car for Australia Day. A survey was undertaken in Western Australia in 2011 to ascertain who flies the flag and why. Results indicate the phenomenon was widespread with a quarter of those surveyed displaying car-flags. A clear relationship between car-flag-flying and exclusionary nationalism is demonstrated. Car-flag-flyers rate more highly on measures of patriotism and nationalism, and feel more negative towards Muslims and asylum seekers, and more positive about the White Australia Policy. They are also significantly more likely to feel their culture and values are in danger, and have a nativist vision of Australian identity. While both groups are positive about Australia's diversity, car-flag-flyers are more likely to feel that migrants should assimilate. The results support other literature that suggests that in some contexts the Australian flag has come to be associated with exclusionary nationalism.

Keywords: flag, Australia, nationalism, racism, patriotism 


\section{Australia Day, flags on cars and Australian nationalism}

\section{Background}

Flags are important symbols in the construction of national identity (Billig, 1995; Spillman, 1997; Smith, 2003; Kemmelmeier \& Winter, 2008; Kwan, 2010; Ward, 2010). While Anderson (1991) noted the importance of the printing press to the nation as an imagined community, before its invention it was the flag that filled this role. Flags perpetuate nationalism in overt, but also covert, ways - when being consciously waved or when hanging unnoticed on public buildings (Billig, 1995, p.8). Both uses produce a taken-for-granted national identity, and in the process, establishing an 'us' and a 'them'.

National symbols such as flags attain meaning through being embedded in cultural practices (Kemmelmeier \& Winter, 2008). Available as part of the 'performance' of nationalism (Dunn, 2009), flags are sites for the contestation of values. Unlike other state symbols (e.g., currency, the coat of arms) the state does not seek to control or monopolise its use. The flag is thus gifted to 'the people' who are encouraged to keep it relevant by proliferating its use (Orr, 2010).

Countries differ in their use of the national flag. In the US the flag is ever-present. Public institutions, including schools, are required to fly the flag, and after the terrorist attacks of $9 / 11$, up to 82 per cent of Americans flew the flag on their homes, car or selves (Skitka, 2005). This created in the American mind an ideological narrative that saw flag flying as patriotic, and not flying it as unpatriotic (Bratta, 2009). In the United Kingdom, ultranationalist fascist groups appropriated the British flag in the 1970 s and 80s, resulting in its public use being generally limited to official buildings and activities associated with the royal family. In Northern Ireland the flag is a highly visible and contentious symbol of different nationalisms - the recent rioting caused by the decision to limit the display of the Union Jack from Belfast City Hall is evidence of this.

Australians historically have not been flag-flyers. Rather, their nationalism has been described as low key, "...laconic and undemonstrative" (Orr, 2010, p.510). They have traditionally been wary of US style nationalism, limiting flag use to official occasions. However the public use of the Australian flag has proliferated in recent years. In line with the growing nationalism observed in a range of countries 
concerned by an increasingly globalised world, this appears to reflect a desire to express national pride by 'owning' the national symbol and investing it with particular meanings. The increased use in Australia is not simply the result of the conservative Howard government's (1996-2007) insistence that schools fly the flag in order to receive government funding (Clark, 2006). It is much more organic and viral in its spread (Orr, 2010). While the flag has been used to display strong nationalist sentiment in public arenas, such as during the Cronulla riots and by anti-immigration politician Pauline Hanson (Noble, 2009), it is more common in its banal uses. These have included the installation of flag poles in homes, and display on cars around Australia Day each year (Huxley, 2009; Orr, 2010).

The flying of flags on cars became popular around Australia Day 2006 in Western Australia (Casellas, 2006), peaking a few years later. Car flags are available for sale some months prior to Australia Day and cars carry them up to 6 months later. The association of flags with Australia Day is not in itself surprising. Australia Day, established as a national public holiday in 1994, has become a day of significant nationalist sentiment (Spillman, 1997; National Australia Day Council, 2011; McAllister, 2012). Such events encourage the expression of popular nationalism (Durkheim, 1995 [1912]; Billig, 1995; Fox, 2006). Street parades, music shows, iconic 'Australiana' competitions (thong throwing, cow-pat bingo, wood chopping), and sausage sizzles, are common (McAllister, 2012, p.95). Western Australia celebrates with particular enthusiasm. For weeks beforehand retailers sell, or give away (eg., with the purchase of a six pack of beer), cheap plastic flags designed for display on cars. Flags are also to be found for sale as temporary tattoos, earrings, headbands, T-shirts, bikinis, thongs, beach towels, balls, and so on, encouraging a "patriotic fashion statement" (Huxley, 2009, p.7) (see Bratta, 2009, for similar merchandising in the US, post 9/11). On the day, Perth (WA's capital) hosts the largest festivities in the nation, with 250,000 to 350,000 people gathering along the Swan River to enjoy a day long program, culminating in a half hour fireworks display set to iconic Australian music. ${ }^{1}$

\footnotetext{
${ }^{1}$ It is likely that Perth's celebrations are enhanced by the fact that, unlike most other Australian capital cities, it does not hold fireworks displays on New Year's eve.
} 
Such overt expressions of nationalism always run the risk of being exclusionary. In 2009 AngloAustralians at Sydney celebrations forced darker skinned revellers to kiss the flag, threatening verbal and physical abuse for non-compliance (Huxley, 2009, p.7; Burke, 2010; McAllister, 2012, p.114).

The association of the flag with a "resurgent, aggressive nationalism" in the Australia Day context (McAllister, 2012, p.114) may be related to similar uses of the flag in other contexts (Perera, 2007; Huxley, 2009; Orr, 2010). Most obvious is the use of the flag during the Cronulla riots in 2005, where several thousand Anglo-Australian young people wore or waved the Australian flag while chanting, "we grew here, you flew here", holding posters saying "Aussies fighting back", with "100 per cent Aussie" written in ink on their skin, or wearing "Wog free" T shirts (Noble, 2009; Perera, 2007, 2010). It has been argued that this was a [re]assertion of Anglo dominance, and a call to arms against an imagined enemy. The rioters may have been influenced by conservative politician Pauline Hanson, who used the flag to signal an exclusionary white Australian identity, draping herself in it to launch her anti-immigration One Nation party (Jupp, 2002; Dunn, 2009; Perera, 2007). Perera (2007, p.12) notes that while the flag was used "as an emblem of racial particularism and aggression" at Cronulla, and again at the Sydney 'Big Day Out' Australia Day concert, politicians and the media failed to make a distinction between "deploying the flag as a celebration of 'harmless' nationalist sentiment and deploying it as an emblem of exclusionary violence". The result, she argues, has been normalising its association with racist displays. She argues these uses of the flag reinforce a racial identification of Australian national identity as British and white, to the exclusion of minorities and the Indigenous population.

As a result of their nation's history, Australians have a complex relationship with diversity and national identity (Maclntyre \& Clark, 2003). Australian nationalism tends to be defensive, "obsessed with border politics where 'worrying' becomes the dominant mode of expression of one's attachment to the nation" (Hage, 2003, p.47). While generally positive about cultural diversity at a surface level, perhaps as a result of 'multiculturalism' becoming part of the nation-building discourse post-White Australia Policy (Moran, 2011), research consistently identifies a simultaneous negativity among Australians towards migrants and such attitudes are becoming more prevalent (Goot \& Watson, 2005; Ipsos, 2011). The 
conservative Howard government enacted a significant shift away from policies and rhetoric supportive of multiculturalism to more traditionalist, monocultural identifications of Australia (Joppke, 2004; Maddox, 2005; Moran, 2005; Jupp, 2002; Curran, 2006; Noble, 2009; Tate, 2009), and consciously associated these values and the politics around them, with the flying of the flag, and with a unique and innate Australian identity (Clark, 2006). This approach has continued, although to a lesser extent, under the Labor Party, which won office in 2007, and whose focus remains on 'integration', 'social cohesion' and 'citizenship' rather than celebrations of diversity (Jacobs \& Malpas, 2011).

This complex relationship is perhaps salient on Australia Day - a day where national identity, and the ironies and contradictions at the heart of Australia's history, are an inevitable focus (McAllister, 2012). While other nations celebrate national days of independence, Australia Day marks the arrival of the first fleet of convict ships to the British colony in 1788, when the Union Jack (not officially replaced until 1954) was raised, symbolizing British dominion over Australia. ${ }^{2}$ For Australia's Indigenous peoples January $26^{\text {th }}$ is remembered as Survival or Invasion Day (Kwan, c2008; McAllister, 2012). This tension provides an undercurrent to any celebrations.

While 'suburban nationalism' is nothing new, its manner and frequency of expression is intensifying (Orr, 2010, p.506) - Anzac Day is increasing in popularity, 'pilgrimages' to Gallipoli and the Kakoda trail are now common, the refrain 'Aussie Aussie Aussie, oi, oi, oi' is internationally known, flag raising is now an unofficial part of the kindergarten day, and bumper stickers proliferate with pictures of the Australian flag (often superimposed on a map of Australia) with captions such as "Support it. Or F*\#k off", and "F@\#k off, we're full". In line with the growing flag-based public expression of nationalism in the US since 9/11 (Bratta, 2009), Australians have come to claim the flag as representing a particular set of values and practices. According to Bratta (2009, p.240) the US flag became associated with the Bush binaries of "good versus evil, ... civilized versus barbarous, and us versus them...Occident and Orient". Media commentary around 2006 and 2007 began to make the same claims about the Australian flag, linking its use in some contexts with racism (Jones, 2006; ABC, 2007; Mulvey, 2007; Huxley, 2009). Huxley (2009:6) suggested that the flag

\footnotetext{
${ }^{2}$ The British flag retains pride of place in the top left hand quadrant of the current design (Kwan, 2010).
} 
had become a symbol of provocation, used as a weapon to divide. As noted, academics have also argued that the flag's symbolic value is to represent those of white Anglo background as the legitimate population of the nation-state, excluding others (Foley, 1996; Perera, 2007):

'Undeniably there is a racial element to some of this [flag use] ...Whether tattooed on the skin, painted on the face and worn to the Cronulla race riots, or brandished at the Big Day Out rock concern, many now appropriate the Australian flag as an expression of a narrow brand of "Aussie" nationalism. In its more militant uses, the flag is wielded confrontationally - as a symbolic weapon - against whichever recently arrived ethnic group is accused of failing to assimilate.' (Orr, 2010, pp.510-511).

The current research asked how prevalent is the phenomenon of car-flag use around Australia Day and what does it represent. We tested the hypotheses that compared to non-car-flag-flyers, car-flag-flyers are more likely to:

(1) express exclusionary nationalism, but show no difference in terms of patriotism; and

(2) express less positivity towards cultural diversity generally and to particular out-groups.

In order to test the common assumption that car-flag-flying is a 'working class' phenomenon, we also investigated education level and socioeconomic status, to test the hypothesis that:

(3) compared to non-car-flag-flyers, car-flag-flyers are more likely to be less educated and have lower socioeconomic status.

\section{DEFINITIONS}

Before proceeding it is necessary to clarify what is meant by terms used to characterise the various phenomena under consideration.

Patriotism and nationalism - The distinction between patriotism and nationalism is more common in the US and among psychology researchers than in the UK and Australia and among sociologists, who tend to use the terms interchangeably. Patriotism is defined as love of one's country and its values, and ingroup solidarity - an affective attachment to one's group (Skitka, 2005). Nationalism, on the other hand, is 
defined as uncritical acceptance of state political authority and belief in the superiority of one's nation compared to others -i.e. out-group antipathy) (Skitka, 2005) ${ }^{3}$. Flying the American flag post-9/11 has been found to indicate patriotism, not nationalism: "to symbolize [Americans] commitment and connections to their fellow citizens, not to declare that the United States was superior and dominant, or that out-groups should beware" (Skitka, 2005, p.2009). In contrast, Kemmelmeier and Winter (2008) found the US flag generated hostile and exclusionary nationalism, and aggressiveness towards other countries, concluding flag-flying is related to nationalism and not patriotism.

Exclusionary nationalism - Since patriotism and nationalism tend to be used interchangeably in Australia, we have used to phrase 'exclusionary nationalism' to signal pride for one's country that includes a derogation of or negativity towards others, including minorities. Exclusionary nationalism is related to ethno-nationalism and racism.

Ethno nationalism and civic nationalism - Ethno nationalism relies on the historical conception of the nation-state as a collective of individuals 'belonging' together on the basis of a shared language, culture, traditions and history (Gellner, 1996). In the context of a settler society it equates to exclusionary nationalism, where minorities who do not share these things are denigrated. Civic nationalism is often contrasted to ethno nationalism. It is a commitment to a common destiny and government through shared civic institutions and the rule of law (Giddens, 1985; Smith, 1991; Habermas, 1994). Civic nationalism is a relatively inclusionary form of nationalism, ethno nationalism is relatively exclusionary.

Nativism - Nativism is "the belief that being 'truly Australian' means being born in Australia, having Australian ancestors, and living here most of our lives" (Goot \& Watson, 2005, p.183). It is related to negativity to immigration and multiculturalism.

Racism; cultural racism/new racism - Racism is an extremely difficult term to define, worse still to measure (Karlson \& Nazroo, 2006). Billiette and de Witte (2008, p.254) define everyday racism as holding negative attitudes towards migrants, where-as other measures of racism focus on discriminatory acts and

\footnotetext{
${ }^{3}$ While connected through positive in-group evaluation, Skitka (2005) provides evidence from factor analysis that patriotism and nationalism are distinguishable constructs.
} 
structures that maintain inequality, rather than attitudes (Karlsen \& Nazroo, 2006). Bulmer and Solomos (1999, p.4), in their introduction to the Oxford Reader on Racism suggest "racism is an ideology of racial domination based on (i) beliefs that a designated racial group is either biologically or culturally inferior and (ii) the use of such beliefs to rationalize or prescribe the racial group's treatment in society". The terms 'cultural racism' and 'new racism' (Barker, 1981; Blaut, 1992) recognise that modern racism is less about assumptions of biological superiority and inferiority, more commonly reflecting a tendency to see the world in terms of cultural hierarchies and maintain practices that exclude certain minority groups on that basis, whether these groups are 'racially' different or not. 'Prejudice' and 'racist' attitudes tend to be used synonymously (Pedersen \& Barlow, 2008; Pedersen et al, 2011).

These definitions serve as ideal types, rather than mutually exclusive categories, and are part of a continuum of pride in the national collective that ranges from patriotism and civic nationalism to racism. We have attempted to elucidate their relationship to the survey items below.

\section{Methodology}

\section{Procedure}

The study was undertaken in Perth, Western Australia. ${ }^{4}$ Data was collected at two points. In the week leading up to Australia Day passers-by were invited to complete the survey by research assistants with clipboards based in several shopping areas and car parks across the wider metropolitan area. On Australia Day itself, eight research assistants and the primary researcher surveyed people gathered at 10 fireworks observation sites, between 10am and 4pm. Sites were mainly designated non-drinking (only on one site, with 41 surveys collected there, was alcohol allowed).

\section{Participants}

In total, 513 people completed the survey; 163 during the week prior to Australia Day, and 350 on Australia Day 2011. 154 reported flying flags on their car in either or both 2010 and 2011, 347 in neither year, and 12 did not respond to the question (and were therefore excluded from the analysis). In order to generate a

\footnotetext{
${ }^{4}$ The project received approval from the relevant Universities' Ethics Committees. Permission was provided by the relevant authorities to conduct surveys at all sites.
} 
larger number of cases for comparison, and because there was no statistical difference between time of completion and flag flying, responses were aggregated. Thus all responses, regardless of site, are dealt with together $(n=501)$.

The majority of participants were male (58 per cent). 34 per cent were aged $18-29$ years, 18 per cent $30-39$ years, and 20 per cent $40-49$ years. Almost three quarters of the sample identified as Australian (52 per cent), Anglo-Saxon-Caucasian (10 per cent) or 'white' (10 per cent). Just over 9 per cent of participants were of Middle Eastern background, 2.4 per cent were Indigenous Australians, and 0.7 per cent of Asian origin (9.6 per cent did not respond to the question). The majority of the sample earned less than $\$ 100,000$ per annum, with 23 per cent earning under $\$ 25,000 ; 20.4$ per cent between $\$ 25,000$ and $\$ 50,000 ; 22.5$ per cent between $\$ 50,000$ and $\$ 75,000$; and 13.7 per cent between $\$ 75,000$ and $\$ 100,000$. In terms of highest level of education attained, 33 per cent had high school level, 26 per cent TAFE (Technical and Further Education) qualifications, and 31 per cent a University Bachelor degree.

\section{Measures}

The survey had three parts. The first was a set of demographic questions. The second consisted of 33 questions pertaining to nationalism and diversity ${ }^{5}$ to which participants responded using Likert-type scales, plus several forced choice responses. The third consisted of five open-ended questions regarding attitudes about the Australian flag, the practice of displaying flags on cars, and the meaning attributed to this practice.

Flag-waving. Participants were asked to indicate whether or not they displayed a flag on their car the year the survey was conducted (2011), and/or the previous year (2010).

Demographic information. Participants were asked their gender, education, age, income level, post-code, voting preference, citizenship status and ethnic identity.

\footnotetext{
${ }^{5}$ As outlined below, a number of questions were taken or adapted from other sources, some of which have been validated. Sources include Goot \& Watson (2005, p.190) (who used the following sources - International Social Survey Program, 1995; Australian Election Study, 1996, 2001; Australian Constitutional Referendum Study, 1999; The Australian Survey of Social Attitudes, 2003); Kemmelmeier \& Winter (2008) and Pedersen \& Paradies, 2010).
} 
Patriotism and Nationalism (See Tables 1, 2, 3, 4). Questions 1, 2, 3, and 4, are based on Kemmelmeier and Winter's (2008) 'patriotism' measures. Questions 9 and 10 reflect 'nationalism' (the questions are based on those used in the International Social Survey Program National Identity II survey; see Goot \& Watson, 2005) as do questions 11,13,14, and 15. A number of the other questions measure aspects of racism, and negativity to cultural diversity, which equate to the nationalism measures of Skitka (2005). Some items in Tables 2 and 3 measure ethno-nationalism (e.g., 24-26, 28-31), others measure civic nationalism (e.g., 21-23). The survey included a set of questions from Goot and Watson (2005), derived from a number of national and international surveys (see also Jones, 2000; Pakulski and Tranter, 2000). One (see Table 2) measures what is seen as required to be 'truly Australian' - participants are presented with nine items (speaking English, feeling Australian, having Australian citizenship, respecting Australia's political institutions and law, living mostly in Australia, being born in Australia, having Australian ancestry, being Christian, and not having an allegiance to another country) and asked to respond on a Likert scale (where 1 $=$ not important and $5=$ very important). Some items measure ethno-nationalism/nativism (living mostly in Australia, being born in Australia, having Australian ancestry, being Christian), others measure civic nationalism.

Positivity towards outgroups (See Table 3). To assess levels of ethno-nationalism or cultural racism, items that measure participants' positivity towards Indigenous Australians, Muslim Australians, asylum seekers, Asian Australians and white Australians, adapted from Pedersen et al (2011; see also Pedersen \& Barlow, 2008) were used. Participants responded on a 5 point Likert-type scale (where $1=$ not at all, and $5=$ very).

Orientations to diversity (See Table 4). Participants were asked to indicate whether they believe it is better for Australian society if groups a) maintain distinct traditions and customs; b) adapt and blend into the larger society; or c) respect and learn from each other's cultural differences. This question, with responses a and b, is taken from the AUSSA survey reported in Goot and Watson (2005), but response c was added for this study.

\section{Results}


Analysis of the results was undertaken by generating descriptive statistics - specifically means of the Likertscale responses and percentages within each response option. T-tests were then conducted to identify significant differences. Four tables conveying the results (percentages and means for the Likert-scale questions, percentages for the non-Likert scale questions) are included below.

In the discussion, in order to allow for ease of comparison between car-flag-flyers and non-car-flag-flyers, percentages calculated by aggregating the two 'agree' response options on the Likert-scales are included.

\section{Flag-waving}

One in five participants reported having flown car-flags to celebrate Australia Day in 2011, the year the research was undertaken, and one in four, the previous year. Car-flag-flyers were significantly more likely to report that they also participated in other 'days' such as Red Nose Day, Wear Pink for Breast Cancer day etc." ( $t$-test, $p<.001)$ indicating car-flag-flyers have a greater propensity to engage in such collective activities generally.

\section{Demographics}

A number of t-tests were conducted to examine whether there were differences between car-flag-flyers and non-car-flag-flyers with regards to demographic characteristics. As hypothesised, car-flag-flyers were significantly more likely to have lower levels of education, compared to non-car-flag-flyers $(p<.001)$. However, there were no significant differences between flag-flyers and non-flag-flyers in terms of their SEIFA $^{6}$ (a measure of comparative socio-economic disadvantage), nor their income levels. Thus, no clear relationship between car-flag-flying and class position was established.

Flag-flyers were more likely to be younger $(p<.001)$ but there was no difference by gender. Those without car-flags in either year were slightly more likely to be Australian citizens (84.2 per cent, $n=280$ )

\footnotetext{
${ }^{6}$ SEIFA (Socio-Economic Indexes for Areas) is a suite of four summary measures created from 2006 Australian Census information. The indexes are used to explore different aspects of socio-economic conditions by geographic areas. Every geographic area in Australia is given a SEIFA number which shows how disadvantaged that area is compared with other areas in Australia. Information is available at http://www.abs.gov.au/ausstats/abs@.nsf/mf/2039.0/
} 
than those with flags (81.4 per cent $n=128$ ), but this difference was not significant. Thus car flag flying is not associated with formal membership of the nation-state ${ }^{7}$.

\section{Patriotism and Nationalism}

A series of t-tests were conducted to examine differences between car-flag-flyers and non-car-flag-flyers on items measuring nationalism and patriotism.

\section{[TABLE 1 ABOUT HERE]}

While clear majorities of both groups saw themselves as patriots, car-flag-flyers were significantly more likely to, compared to non-car-flag-flyers (84.7 per cent versus 60.2 per cent) (see Table 1). Car-flagflyers were also significantly more likely to agree that they are "glad to be Australian" (96.0 per cent, compared to 88.3 per cent); that public schools should begin each day with the National Anthem (55.2 per cent, compared to 36.4 per cent); and that "Australia suffers when patriotism decreases" (69.1 per cent, compared to 48.8 per cent).

What is the source of this patriotism? Respondents were asked how proud they felt about seven items relating to Australian life. For six of the seven items, respondents with car-flags felt more pride than those without flags; and this difference was significant for all but two items (multiculturalism and economic success). Levels of pride in Australia's sporting achievements were highest for both groups (flag-flyers 87.6 per cent, non-flag-flyers 82.7 per cent). Participants were almost as proud of Australia's economic success (77.5 per cent, versus 74.4 per cent); technical and scientific success (76.8 per cent, versus 66.7 per cent); and cultural achievements (67.8 per cent, versus 60.6 per cent). 68.5 per cent of flaggers were proud of Australia's history, while non-flaggers were more ambivalent at 50 per cent. 59.9 per cent of flaggers indicated they were proud of Australia's political power compared to 42.8 per cent of non-flaggers. Australia's multiculturalism was the only item where more pride was expressed by those without flags (67.5 per cent, compared to 66.2 per cent), and this difference was not significant.

\footnotetext{
${ }^{7}$ Around $85 \%$ of the Australian population are citizens, the remainder consisting of permanent residents, tourists and those on temporary visas. The slight overrepresentation of non-citizens in the car-flying sample could demonstrate over-compensation to signify one's symbolic allegiance to the nation-state. However, as the difference was not statistically significant, little can be concluded from this result, apart from the fact that citizens are not overrepresented.
} 
In sum, both groups were proud of Australia, but car-flag-flyers were generally more proud. Noncar-flag-flyers were more ambivalent about Australia's history and political power, but sporting successes, economic strength, technical and scientific success, cultural achievements and multiculturalism were sources of pride for a majority of both groups.

Car-flag-flyers' pride in Australia translated into positivity towards Australia's influence over other nations and in the region. Thus they were significantly more likely to agree that "Australia is an important part of the 'Free World'" (88.8 per cent, compared to 79.3 per cent); that "the more influence Australia has on other nations, the better off they are" ( 60.4 per cent, compared to 45.6 per cent) and that "Australia is the most important country in the Asia-Pacific region" (67.4 per cent, compared to 44.8 per cent).

In contrast, non-car-flag-flyers were significantly more likely to agree that "Asian culture has helped to make Australia a far more interesting place" (49.2 per cent, compared to 39.3 per cent), indicating a degree of positivity towards the influence of Asia on Australia, rather than vice versa.

The main measure of exclusionary nationalism in this set of questions was an item measuring levels of support for an explicitly exclusionary immigration policy, i.e. whether respondents believed the White Australia Policy had "saved Australia from many problems experienced by other countries". 40.7 per cent of those with car-flags agreed, significantly higher than the 23.9 per cent for those without flags. It must be noted that majorities of both groups did not agree with the statement.

Car-flag-flying was also associated with a sense of threat to one's culture and values. While four out of ten of the total sample feared their culture and its most important values were in danger, this was significantly higher for car-flag-flyers (a majority at 54.1 per cent) than non-car-flag-flyers (31.3 per cent).

Car-flag-flyers were significantly more likely to agree that "having a flag on one's car is a way of showing that one is proud to be Australian" (84.4 per cent, versus 48.4 per cent) and "indicates that the person is more patriotic than most" (35.3 per cent, versus 18.5 per cent).

People with car flags indicated higher levels of agreement than those without for all nine items related to perceptions of what it means to be truly Australian (See Table 2). However, interestingly, both groups rated 'civic' nationalism items more highly than 'ethno' nationalism or nativist items. 
Of the nine items, showing respect for Australia's political institutions and laws rated most highly for both flaggers (97.4 per cent) and non-flaggers (95.4 per cent). This was the only item for which there was no statistical difference between the two groups. Speaking English was almost as important for both groups (94.1 per cent of flaggers, 86.7 per cent of non-flaggers). Living mostly in Australia was also an important indicator for flaggers, at 82.2 per cent, less so for non-flaggers (66.4 per cent), with a similar pattern for Australian citizenship (80.3 per cent, versus 65.7 per cent).

Sense of attachment was important for both groups. Majorities agreed that feeling Australian was very important, although this was almost unanimous for car-flag-flyers ( 91.9 per cent), but significantly less important for non-flaggers (67.5 per cent).

Indicating the importance of ethno-nationalism/nativism to car-flag-flyers, 39.5 per cent believed being born in Australia was important to being truly Australian (compared to non-flaggers at 18.3 per cent); 36.9 per cent agreed having Australian ancestry was important (compared to 14.4 per cent); and 23.2 per cent felt being Christian was important (compared to 16.9 per cent). ${ }^{8} 31.7$ per cent of car-flag-flyers felt it was important not to have an allegiance to another country (significantly more than the 20.2 per cent among non-flag-flyers).

\section{Positivity towards outgroups, and orientations towards diversity}

To measure comparative levels of exclusionary nationalism, participants were asked how positive they feel towards a range of ethnic groups. While a blunt measure, this provides some insight into general

\footnotetext{
${ }^{8}$ It is worthy of note that two measures were much lower for both groups than the 2003 results reported by Goot and Watson. 39.5 per cent of flaggers and 18.3 per cent of non-flaggers felt that people had to be born in Australia to be truly Australian - 24.9 per cent overall. This is much lower than the 58 per cent reported by Goot and Watson (2005, p.188). Similarly 23.2 per cent of flag-flyers believed that true Australians had to be Christian, compared with 16.9 per cent of non-flaggers, whereas Goot and Watson report the 2003 figure at 36 per cent $(2005$, p.188). The massive difference between the 2003 figures and the current results is perhaps surprising given the stability of the result that Goot and Watson report over the decade to 2003. While the current sample is not representative, it is a sample for whom nationalism was salient, given the Australia Day context. Additionally, the years post-2003 saw strong nationalist sentiment encouraged at the highest political levels. One might therefore expect higher, not lower, figures. The fact that car-flag-flyers were far less likely than the general population in 2003 to require these 'nativist' characteristics as measures of true Australian-ness may indicate that nativist definitions have declined. Without testing among a representative sample this remains conjecture.
} 
orientations to diversity. The results indicate clear differences (see Table 3). Positivity towards Muslims and asylum seekers was very low among both car-flag-flyers and non-car-flag-flyers, but was significantly lower among flag-flyers. 19.6 per cent of flaggers felt positive towards Muslim Australians compared with 26.8 per cent of non-flaggers; and 9.9 per cent of flaggers were positive towards asylum seekers (versus 24.7 per cent). 38.8 per cent of car-flag-flyers felt positive towards Asian Australians compared with 48.6 per cent of non-flaggers. There was no significant difference between flag-flyers and non-flag-flyers in terms of positive attitudes towards Aboriginal Australians (43.2 per cent versus 45.6 per cent). ${ }^{9}$

\section{[TABLE 3 ABOUT HERE]}

In terms of attitudes to diversity, results replicate the contradictions identified in earlier research. Three questions sought views on Australian cultural diversity, and results for all items demonstrated significant differences between car-flag-flyers and non-car-flag-flyers. A majority of both groups agreed it is good for people from different ethnic, religious and racial groups to live in Australia (64.7 per cent of carflag-flyers, 77 per cent of non-flaggers). However, a majority of both groups also felt that people who move to Australia should adopt Australian values (88.3 per cent of people with car-flags, 74.2 per cent of nonflaggers). Relatedly, over half (52.9 per cent) of car-flag-flyers believed migrants should leave their old ways behind, compared with only a quarter (26.7 per cent) of non-flaggers.

Participants were also asked which would be the better approach for Australian society in terms of dealing with internal diversity (Table 4). Only one in ten flag-flyers and non-flag-flyers agreed groups should maintain distinct traditions and customs, but similarly only a fifth of non-car-flag-flyers and a third of flagflyers felt the appropriate response was for minorities to adapt and blend into the larger society. Instead, clear majorities of both groups selected the third option, not included in previous surveys, seeing it as more appropriate to "respect and learn from each other's cultural differences" (73.5 per cent, and 61.2 respectively). Thus for both groups integration rather than assimilation appears to be the preferred option.

\section{[TABLE 4 ABOUT HERE]}

\footnotetext{
${ }^{9}$ Interestingly, only 59.8 per cent of non-flag-flyers were positive about white Australians, compared to 63.4 per cent of flag-flyers (one of the few non-significant differences overall). 33 per cent of both groups chose the neutral column for this question, and very few selected 'not at all'.
} 


\section{Discussion and Conclusion}

We sought to determine whether Australia Day car-flag-flyers are more likely than non-car-flag-flyers to express exclusionary nationalism, but not patriotism. The results indicate that car-flag-flyers rate more highly on measures of exclusionary nationalism, but also on other forms of nationalism (such as civic nationalism), and of patriotism.

We also sought to determine whether car-flag-flyers are more likely than non-car-flag-flyers to be less positive about cultural diversity and out-groups. This hypothesis was also confirmed. Car-flag-flyers were significantly less positive about Australia's diversity generally, and about Muslim and Asian Australians and asylum seekers specifically; and more likely to support assimilation of migrants. They were also more fearful that their culture and values are under threat, supporting Hage's $(2003, p .47)$ argument that Australian nationalism is associated with defensiveness and worry (see also Dandy \& Pe-Pua, 2010).

Some evidence was provided that Australia Day car-flag-flying is a 'working class' phenomenon, with a relationship demonstrated between it and education level, but not socioeconomic status.

For all measures indicating levels of patriotism, nationalism and attitudes to diversity, car-flagflyers rated higher (on patriotism and nationalism) and lower (on positivity to diversity) compared to noncar-flag-flyers, and most of these differences reached statistical significance. While individual results for specific questions speak to the hypotheses, this cumulative effect is a powerful indicator that car-flag use is associated with exclusionary nationalism or cultural racism. The effect is even more striking as the survey was conducted among a population for all of whom, it can be assumed, national pride was salient, given the Australia Day context. The results indicate, as suggested by earlier commentators, that for some, though clearly not all, car-flag-flying may be about asserting a particular version of the nation. Historically, flags were about signalling sides in battle, and it appears "elements of this signalling of 'insider' versus 'outsider' remain..." (Orr, 2010, p.521).

The results are of particular interest given the current environment where globalisation has been predicted to reduce the importance of national identifications, encouraging instead a growth of cosmopolitan and post-national identities and orientations, and gradually eliminating the need for any form 
of state-level belonging whatsoever (Hedetoft \& Hjort, 2002; Beck, 2006; Werbner, 2008). Rather than the more inclusive identities and orientations to difference foreseen by some (Beck, 2006; Norris \& Inglehart, 2009; Wise \& Velayutham, 2009; Ariely, 2012), Australian nationalism appears alive and well and the flag appears to have come to represent, to some Australians, an identity associated with the majority culture and race, and exclusive of difference. These results appear to support the suggestion that globalisation may lead to rising levels of xenophobia, rather than greater cosmopolitanism (Joppke, 2004; IPSOS, 2011).

Bratta (2009) argues one cannot modify the narrative of the flag once it is fixed in the public sphere. Thus the use of the flag in an exclusionary way at Cronulla, by Pauline Hanson and in racist bumperstickers, cements a certain message within it. Perera (2007, p.13) suggests that post-Cronulla there is "almost a naturalised relationship between the flag, Anglo-Australian identitarianism and racist violence". Its viral replication on cars re-transmits this message, but only partially. The effect is not total, as clearly some people with car flags are positive about diversity, do not feel their values and way of life are under threat, and do not view minorities in a negative way.

A further observation is worthy of note. Regardless of car-flag-flying status, the levels of negativity about minorities, exclusionary definitions of what it means to be truly Australian, and agreement with the statement that the White Australia Policy saved Australia from many problems, are troubling. The fact that one out of four non-car-flag-flyers, for instance, agreed with this latter statement, indicates that a strain of negative race-based nationalism is reasonably widespread.

In January 2012 the results of the study were publicised in a press release, producing an enormous response (see Fozdar, under review). The suggestion that the Australian flag might in some contexts be associated with racist attitudes caused a massive public outcry. This sensitivity reinforces the observation that the flag has taken on a strong symbolic value in the minds of the Australian people, whose relationship to it is no longer 'laconic and undemonstrative'. While qualitative data from the study indicated that people were not particularly conscious of their reasons for flying the flag on their cars, they were nevertheless highly insulted by the suggestion that it might signal negative forms of nationalism. 
Is it possible to conclude that the Australian flag has come to stand for exclusionary nationalism? Not absolutely, for all uses of the flag are contextual. But it seems clear that with the change in uses of the flag, the growth in public 'ownership' of it, and its increasing importance as a symbol aligned with a certain version of Australian identity, there is a danger that it may be becoming so. The question then becomes one of whether its rehabilitation is possible.

\section{References}

ABC (Australian Broadcasting Commission). (2007). Raising the flag. Compass, Transcript 1 July 2007. Retrieved from http://www.abc.net.au/compass/s1967604.htm

Anderson, B. (1991) Imagined Communities: Reflections on the origins and spread of nationalism (Revised and Extended Edition ed.). London, England: Verso: New Left Books.

Ariely, G. (2012). Globalisation and the decline of national identity? An exploration across sixty-three countries. Nations and Nationalism, 18(3), 461-482.

Barker, M. (1981). The New Racism: Conservatives and the Ideology of the Tribe. London: Junction Books.

Beck, U. (2006). The Cosmopolitan Vision. Cambridge: Polity Press.

Billiet, J., \& de Witte, H. (2008). Everyday racism as predictor of political racism in Flemish Belgium. Journal of Social Issues, 64(2), 253--267.

Billig, M. (1995). Banal Nationalism. London: Sage Publications.

Blaut, J. (1992). The theory of cultural racism. Antipode, 24(4), 289-299.

Bratta, P. (2009). Flag display post-9/11: A discourse on American nationalism. The Journal of American Culture, 32(3), 232-243.

Burke L (2010) Horror Show of Aussie Celebrations. The West Australian, 26 October.

Bulmer, M., \& Solomos, J. (1999). Racism. Oxford: Oxford University Press.

Casellas, S. (2006). They're just rolling along. The West Australian, 27 January 2006, 9. 
Clark, A. (2006). Flying the flag for mainstream Australia. Griffith Review (Getting Smart: The Battle for Ideas in Education), Edition 11.

Curran, J. (2006) The Power of Speech: Australian Prime Ministers Defining the National Image. Melbourne: Melbourne University Press.

Dandy, J., \& Pe-Pua, R. (2010). Attitudes to multiculturalism, immigration and cultural diversity: Comparison of dominant and non-dominant groups in three Australian states. International Journal of Intercultural Relations, 34(1), 34-46.

Department of Immigration and Citizenship. (2010). Fact Sheet 4 - More than 60 years of post-war migration. Media. Retrieved from http://www.immi.gov.au/media/fact-sheets/04fifty.htm

Dunn, K (2009) Performing Australian Nationalism at Cronulla. In G. Noble (Ed) Lines in the Sand: The Cronulla Riots, multiculturalism and national belonging. Annandale, Sydney: The Institute of Criminology Press.

Durkheim, E. (1995). The Elementary Forms of Religious Life. First published in French in 1912. New York: The Free Press.

Foley C A (1996) The Australian Flag: Colonial Relic or Contemporary Icon? Leichhardt, NSW, Australia: The Federation Press.

Fox, J. (2006). Consuming the nation: Holidays, sports and the production of collective belonging, Ethnic and Racial Studies, 29(2), 217-236.

AUTHOR. (under review, Nations and nationalism). 'Flagging nationalism'.

Gellner, E. (1996). The coming of nationalism and its interpretation: The myths of nation and class. Mapping the Nation. New York: New Left Books.

Giddens, A. (1985). A Contemporary Critique of Historical Materialism. Cambridge: Polity Press. 
Goot, M., \& Watson, I. (2005). Immigration, multiculturalism and national identity. In S. Wilson, G. Meagher, R. Gibson, D. Denemark, \& M. Western (Eds.), Australian Social Attitudes (pp.182-203). Sydney: NSW Press.

Habermas, J. (1994). Struggles for recognition in the democratic constitutional state. In A. Gutmann (Ed.), Multiculturalism: Examining the Politics of Recognition (pp.107-147). Princeton: Princeton University Press.

Hage, G. (2003). Against Paranoid Nationalism: Searching for Hope in a Shrinking Society. Sydney: Pluto Press.

Hedetoft, U \& Hjort, M (2002) The Postnational Self: belonging and identity. Minn, U of Minnesta Press.

Huxley, J. (2009). When patriotism becomes provocation. The Sydney Morning Herald (Weekend Edition, News Review), 31 January 2009, 6.

Ipsos. (2011). Global views on immigration. Global @dvisor. Retrieved from http://www.ipsos.fr/sites/default/files/attachments/globaladvisor immigration.pdf

Jacobs, K., \& Malpas, J. (Eds.) (2011). Ocean to Outback: Cosmopolitanism in Contemporary Australia. Perth: University of Western Australia Publishing.

Jones, B. (2006). Racism draped in a flag. The Sydney Morning Herald, January 28 2006. Retrieved from http://www.smh.com.au/news/opinion/racism-draped-in-flag/2006/01/27/1138319443954.html

Jones, F. L. (2000). Diversities of National Identity in a Multicultural Society: The Australian Case. National Identities, 2(2), 175-186

Joppke, C. (2004). The retreat of multiculturalism in the liberal state: Theory and policy. The British Journal of Sociology, 55(2), 237-257.

Jupp, J. (2002). From White Australia to Woomera: The Story of Australian Immigration. Cambridge, England: Cambridge University Press.

Karlsen, S., \& Nazroo, J. (2006). Measuring and analyzing 'race', racism, and racial discrimination. In J. Oakes \& J. Kaufman (Eds.), Methods in Social Epidemiology (pp.86-111). Jossey Bass: San Francisco. 
Kemmelmeier, M., \& Winter, D. (2008). Sowing patriotism, but reaping nationalism? Consequences of exposure to the American flag. Political Psychology, 29(6), 859-879.

Kwan, E. (2010). Flag. In M. Harper, \& R. White (Eds.), Symbols of Australia: Uncovering the Stories Behind the Myths (pp.98-105). Sydney/Canberra: University of New South Wales Press Ltd \& National Museum of Australia Press.

Kwan, E. (c2008). Celebrating Australia: A history of Australia Day. Retrieved from http://www.australiaday.org.au/media/42069/australia per cent20day per cent20history per cent20pdf.pdf Leunig, M. (2007). 'Dinkum Aussie Australia Day', diary. The Saturday Age, A2, 27 January 2007, 52.

Maclntyre, S., \& Clark, A. (2003). The History Wars. Melbourne: Melbourne University Press.

Maddox, M. (2005). God Under Howard: The Rise of the Religious Right in Australian Politics. Crows Nest, NSW: Allen and Unwin.

McAllister, P. (2012). National Days and the Politics of indigenous and Local Identities in Australia and New Zealand. Durham, North Carolina: Carolina Academic Press.

Moran, A. 2011 Multiculturalism as(2005). Australia: Nation-building in Australia: Inclusive National Identity and the Embrace of Diversity. Ethnic and Racial Studies 34(12): 2153-2172.

Moran, Anthony. 2005. Australia: Nation, belonging and globalization., Belonging and Globalization. New York: Routledge.

Mulvey, P. (2007). Flags 'not banned' but unwelcome. News.com.au, 22January 2007. Retrieved from http://www.news.com.au/story/0,27574,21095538-2,00.html

National Australia Day Council. (2011). A wonderful Australia Day 2011. News and Media, January 25. Retrieved from http://web.archive.org/web/20110129180032/http://www.australiaday.org.au/media/?x=64

Noble, G. (2009). Lines in the Sand: The Cronulla Riots, Multiculturalism and National Belonging. Sydney: Institute of Criminology Press. 
Norris, P., \& Inglehart, R. (2009). Cosmopolitan Communications: Cultural Diversity in a Globalized World. Cambridge: Cambridge University Press.

Orr, G. (2010). A fetishised gift: The legal status of flags. Griffith Law Review, 19(3), 504-526.

Pakulski, J., \& Tranter, B. (2000). Civic, national and denizen identity in Australia. Journal of Sociology, 36(2), 205-222.

Pedersen, A., Paradies, Y., Hartley, L., \& Dunn, K. (2011). Bystander antiprejudice: Cross-cultural education, links with positivity towards cultural 'outgroups' and preparedness to speak out. Journal of Pacific Rim Psychology, 5(1), 19-30.

Pedersen, A., \& Barlow, F. (2008). Theory to social action: A university based strategy targeting prejudice against Aboriginal Australians. The Australian Psychologist, 43, 148-159.

Perera, S. (2010). From 'sovereignty' to 'sustainability': The loops and lineaments of exclusion 2001-2010. In S. Perera, G. Seal, \& S. Summers (Eds.), Enter at Own Risk? Australia's Population Questions for the 21st Century (pp.1-28). Perth, Western Australia: Black Swan Press.

Perera, S. (2007). 'Aussie luck': The border politics of citizenship post Cronulla Beach. Australian Critical Race and Whiteness Studies Association Journal, 3(1), 1-16. Retrieved from http://www.acrawsa.org.au SBS Immigration Nation. Available at http://www.sbs.com.au/immigrationnation/videos/20/wednesday-16-february-8-30pm-sbstwo\#related (accessed 23 February 2010)

Skitka, L. (2005). Patriotism or nationalism? Understanding post-September 11, 2001 flag display behavior. Journal of Applied Social Psychology, 35, 1995-2011.

Smith, A. (2003). Chosen Peoples. Oxford: Oxford University Press.

Smith, A. (1991). National Identity. Harmondsworth, London: Penguin.

Spillman, L. (1997). Nation and Commemoration: Creating National Identities in the United States and Australia. New York: Cambridge University Press. 
Tate, J. (2009). John Howard's 'nation' and citizenship test: Multiculturalism, citizenship and identity. Australian Journal of Politics and History, 55(1), 97-120.

van Dijk, T. (1987). Communicating Racism: Ethnic Prejudice in Thought and Talk. Newbury Park, California: Sage.

Ward T (2010) Sport in Australian National Identity: Kicking Goals. Milton Park, UK: Routledge.

Werbner, P (2008). Anthropology and the New Cosmopolitanism: Rooted, Feminist and Vernacular Perspectives. ASA Monograph No. 45. Oxford: Berg Publishers..

Wise, A \& Velayutham, S (2009). (eds.) Everyday Multiculturalism. Houndsmills, England: Palgrave Macmillan. 